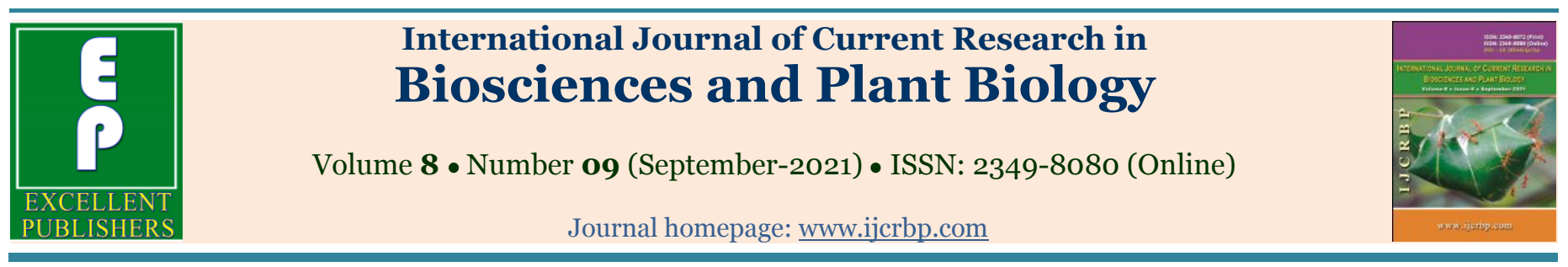

\title{
Effect of nursery substrate on the growth of Pterocarpus erinaceus Poir. seedlings
}

\section{Pyoabalo ALABA ${ }^{1}{ }^{1}$, Atti TCHABI ${ }^{2}$, Komla Elikplim ABOTSI ${ }^{1}$, Kossi ADJONOU ${ }^{1}$, Kossi Novinyo SEGLA ${ }^{1}$, Adzo Dzifa KOKUTSE ${ }^{1}$, Kouami KOKOU ${ }^{1}$}

\author{
${ }^{1}$ Laboratoire de Recherche Forestière, Université de Lomé, O1BP1515, Lomé, Togo \\ ${ }^{2}$ Institut Supérieur des Métiers de l'Agriculture, Université de Kara, BP: 43 Kara-Togo \\ *Corresponding author; e-mail: pyoalaba@yahoo.fr
}

\begin{abstract}
Article Info
Keywords:

Chemical nutrients

Microorganisms

Pterocarpus erinaceus

Seedlings growth

West Africa

Abstract

The high pressures on Pterocarpus erinaceus Poir. severely affect its natural stands in West Africa. The measures taken to reverse this trend are still inefficient due to plantlets production constraints. This study aims to understand the importance of growing substrates on seedlings growth in nursery. Composite soil samples were collected at $20 \mathrm{~cm}$ depth from 4 seed trees in 5 different sites in Togo (West Africa). Two batches were made for each site, one of which was sterilized by autoclave and the other has received no treatment. Three growing parameters (length of stem, number of buds and number of leaves) of the plantlets obtained from sterilized seeds were measured during 20 weeks in the nursery. Results show for each site a significantly better growing rate of seedlings on unsterilized substrates, compared to sterilized substrates. At the end of the experiment, plantlets were $8.75 \pm 2.32$ $\mathrm{cm}$ mean height on sterilized substrates when they reach $19.20 \pm 5.00 \mathrm{~cm}$ on unsterilized substrates. The mean number of buds and leaves per plantlet varies from $2.23 \pm 1.71$ buds and $3.00 \pm 1.86$ leaves to $10.73 \pm 3.28$ buds and $11.09 \pm 2.48$ leaves at the same date, respectively on sterilized and unsterilized substrates. The low growing rate on sterilized substrates should be linked to the low capacity of plantlets in mobilizing phosphorus, potassium and nitrogen without microorganisms. Negative impacts of sterilization were highlighted on seedlings by necrosis of buds and leaves from the 7th week of growth, demonstrating a positive effect of soil microorganisms on the proper development of the seedlings.
\end{abstract}

- Received: 23 June 2021 • Revised: 26 August 2021 • Accepted: 29 August 2021 • Published Online: 6 September 2021

\section{Introduction}

Global objectives of sustainable development impose enormous challenges in terms of environmental management and particularly on issues related to degradation of forest ecosystems and loss of biodiversity (Alkemade et al., 2009; Giddings et al.,
2002). Considering the management of these paradigms could significantly positively influence the sustainability of ecosystem goods and services essential to improve the living conditions of populations. The many pressures on forest ecosystems, especially in tropical areas, for the provision of ecosystem goods and services are compromising the survival of species of 
high socio-economic value such as Pterocarpus erinaceus Poir. (Rabiou et al., 2017b; Segla et al., 2015a). This species is widely used in West Africa for the treatment of several diseases, in the manufacture of tools (Dumenu, 2019; Segla et al., 2015a) and also as fodder (Nacoulma et al., 2011; Solly et al., 2020).

$P$. erinaceus timber has been very well prized by economic operators in the timber sector throughout the West African sub-region since 2000 (Adjonou et al., 2010). In Togo, its exploitation reached record levels, with volumes intended for export growing from 3,500 $\mathrm{m}^{3}$ in 2007 (Adjonou et al., 2010) to $9,690 \mathrm{~m}^{3}$ in 2012 (Segla et al., 2016), and more than $183,131 \mathrm{~m}^{3}$ only for the year 2014 according to official figures. The interest in this wood is justified by its exceptional physical and mechanical properties which make it suitable for different uses (Segla et al., 2015b). Its wood has a density of $0.88 \mathrm{~g} / \mathrm{cm}^{3}$ with low tangential and radial shrinkage $(5.8 \%$ and $3.3 \%$ respectively) and a lower shrinkage anisotropy, making it a hardwood and stable multipurpose material.

Many kinds of pressures exerted on P. erinaceus have had negative impacts on its stands (Nacoulma et al., 2011; Solly et al., 2020). These pressures impact the development and regeneration of the species, making it one of the most endangered species in Burkina Faso and Niger (Nacoulma et al., 2011). This is why it is now included on the Red List of the International Union for Conservation of Nature (IUCN) in the category of "Endangered" species (IUCN, 2020).

To stem the extinction of $P$. erinaceus, a better management and silviculture is essential as a lasting solution insofar as the species is an integral part of the socio-cultural and economic heritage of countries in the West African sub-region (Rabiou et al., 2017b). To date, attempts at domestication and silviculture of the species have yielded contrasting results. The use of cuttings has shown that even if there are difficulties in obtaining budding and bud break on stem fragments (Rabiou et al., 2017a), thicker fragments of more than 2 $\mathrm{cm}$ at section offer good prospects for the reproduction of the species by cuttings, especially when using Indole Acetic Acid (IAA) as growth hormone (Ouinsavi et al., 2019). Similar works have shown that air layering is also possible with 3 to $4 \mathrm{~cm}$ in diameter stems (Rabiou et al., 2017a). In spite of all these results, vegetative propagation methods have limits; on the one hand on their capacity to provide a large number of seedlings to meet the needs of large-scale reforestation at country level and on the other hand, in complexity of these multiplication techniques that complicated their adoption by planters and seedling producers (Alaba et al., 2020). Otherwise, it has been demonstrated that the seeds of $P$. erinaceus have a good germination rate (Bamba et al., 2018) which would offer good prospects for massive production of plants intended for large-scale reforestation. Despite the high potential for seed germination (Bamba et al., 2018; Zida et al., 2005), multiplication of $P$. erinaceus by seed also has limitations. Indeed, the young plants cross the first years of life with difficultly and show low growth rate (Duvall, 2008).

In addition, previous works have shown that the distribution of plant species in the natural environment is determined by ecological factors such as the chemical composition of the soil (Imane et al., 2019; Neyra et al., 2012). What then are the chemical characteristics of the environment that determine growth and survival of young seedlings reared in nurseries?

Other studies have also indicated that microorganisms play an essential role in improving the growth and survival of plants, particularly by increasing the bioavailability of mineral elements, which generally constitute the main constraint on their growth (Abbas et al., 2013; El-Siddig, 2006; Sali et al., 2011). Furthermore, it is reported that some plant species cannot grow normally without associating with one or more symbiotic microorganisms (Gobat et al., 2010; Meena et al., 2017; Rincón et al., 2008). Understanding what role soil microorganisms play in the survival and growth of young seedlings in nursery then becomes crucial.

This study aims to help overcome the constraints on survival and growth of $P$. erinaceus seedlings in the nursery for the needs of intensive production. Specifically, it aims to analyze (i) the importance of soil microorganisms on the growth of seedlings and (ii) the influence of chemical characteristics of the substrate on the growth of $P$. erinaceus seedlings in nursery.

\section{Materials and methods}

\section{Study area}

The study is based on plant material and substrates collected in 5 protected areas in Togo (Fig. 1). The choice of sites was made to cover the ecological 
variability (Ern, 1979) of the preferred area of occurrence of Pterocarpus erinaceus in Togo (Adjonou et al., 2020). The affected sites are located in the OtiKeran-Mandouri National Park - OKM (1007'19.87 "N, 0 55'53'08" E; ecological zone I), the FazaoMalfakassa National Park - FMNP ( 8॰51'21.7 "N, $0^{\circ} 56^{\prime} 41.89 " \mathrm{E}$; ecological zone II), the Abdoulaye wildlife reserve $\left(8^{\circ} 46^{\prime} 31.02 \quad " N, 1^{\circ} 26^{\prime} 56.84^{\prime \prime} \quad \mathrm{E}\right.$; ecological zone III), the community forest of Hahomegbe $\left(6^{\circ} 57^{\prime} 06.67\right.$ "N, $1^{\circ} 02^{\prime} 40.60^{\prime \prime} \mathrm{E}$; ecological zone III) and the Togodo national park $\left(6^{\circ} 55^{\prime} 23.36\right.$ "N, $1^{\circ} 26^{\prime} 09.95$ "E; ecological zone V).

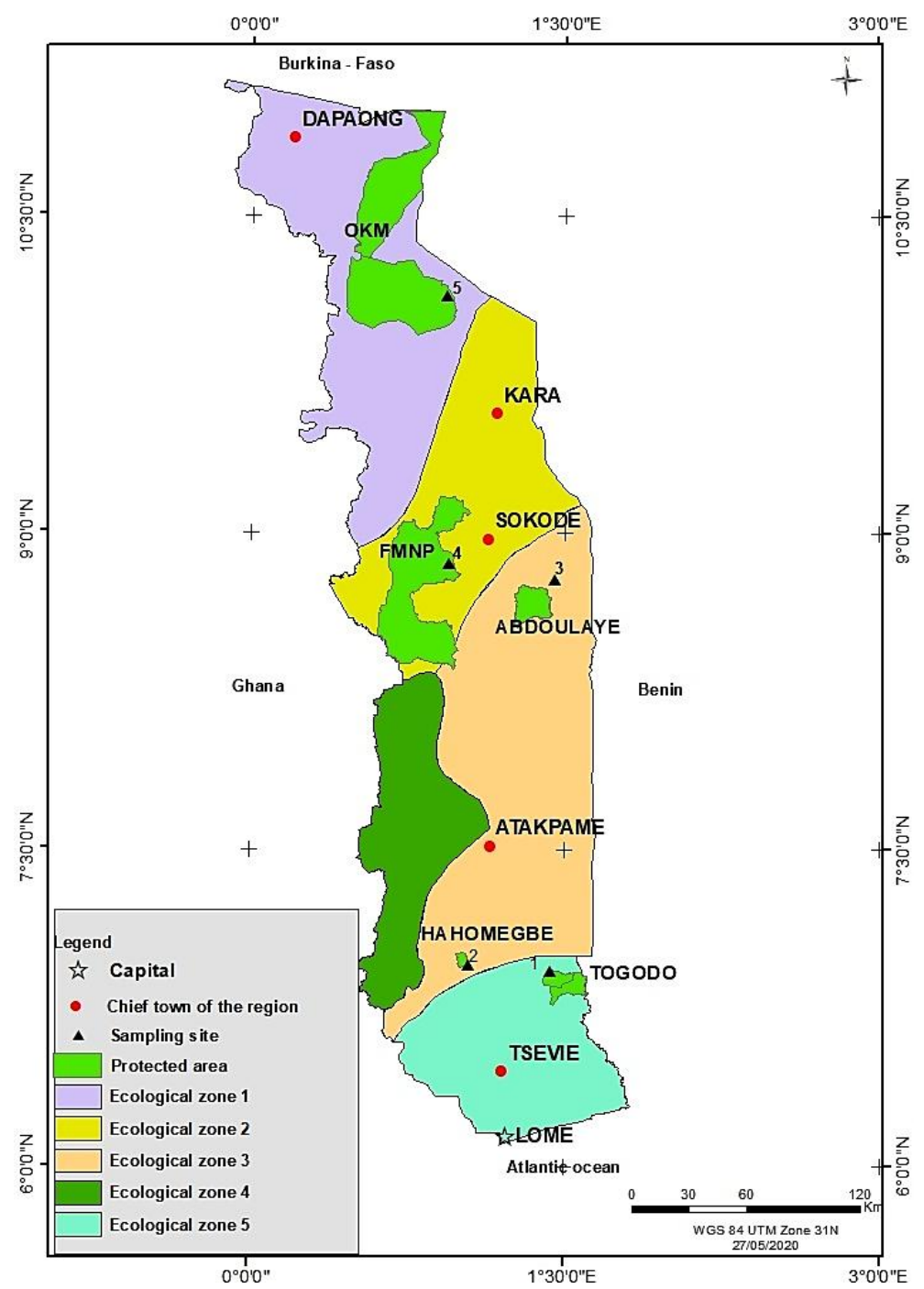

Fig. 1: Location of sites where seeds and substrates were collected. OKM: Oti-KéranMandouri national park; FMNP: Fazao-Malfakassa National Park.

Ecological zone I corresponds to the plains in the extreme north of the country, subjected to a Sudanesetype climate with annual precipitation varying between 800 and $1000 \mathrm{~mm} /$ year. The predominant vegetation is the Sudanese savannah, with a few patches of dense dry forests and forest galleries along the rivers. Ecological zone II corresponds to the northern part of the Togo Mountains. Its vegetation is made up of a mosaic of dry mountain forests and forest galleries. The climate is Sudano-Guinean type, receiving 1200-1600 mm / year of precipitation. Ecological zone III (central plains) is mainly covered by the Guinean savannah with a tropical Guinean climate and rainfall of 1000-1500 mm / year. There are pockets of semi-deciduous forests and dense dry forests. Ecological zone $\mathrm{V}$ enjoys a dry subequatorial climate, with a rainfall between 800 and $1200 \mathrm{~mm} /$ year. It is covered with a mosaic of savannas, dense semi-deciduous forests and typical wetland ecosystems such as mangroves, flood savannas and flood plains (Ern, 1979). 


\section{Methods}

The experimental design is a 2-level factorial test: (i) the "biological characteristic of the substrate" factor which consists of sterilized substrate on the one hand and unsterilized (native soil) substrate on the other hand; (ii) the "chemical characteristic of the substrate" factor which comprises 5 levels corresponding to 5 provenances of substrate.

\section{Collection of growing substrates}

At each of the 5 sites, soil samples were collected at 20 $\mathrm{cm}$ depth under 4 different fertile trees of $P$. erinaceus selected randomly in the habitat with a minimum distance of $100 \mathrm{~m}$ between trees. All the soil samples collected from each of the seed companies were made up of a composite sample from the site considered and labelled.

All the substrate samples collected at each site were mixed up to make a composite sample of the site considered. The chemical analyses of the collected substrates were performed at the referral soil laboratory of the Togolese Institute of Agronomic
Research (ITRA). The chemical characteristics of the collected substrates were as recorded in Table 1 .

\section{Substrate preparation}

For each site, the composite substrate was subdivided into 2 batches. A first batch consisted of the fresh, unsterilized substrate constituting the control for the site in the experimental design. The second batch of each site was sterilized in an autoclave at a temperature of $120^{\circ} \mathrm{C}$ and under a pressure of $1.2 \mathrm{bar}$ for 1 hour (Riedacker, 1993) in order to eradicate microorganisms. Each batch was used to fill 45 pots each with $2 \mathrm{~kg}$ of substrate (polyethylene pots), taking care to avoid mixing of substrates or dust from the two batches. The final experimental design consists of 5 sets of 9 pots (repetition), belonging to the 5 sites for each of the 2 batches of substrate. The pots filled with substrate in a batch were placed on 10 wooden trays of $1.2 \mathrm{~m}^{2}$ each at $1 \mathrm{~m}$ height, to allow the water overflow from the pots to flow downwards in the event of excessive watering. Each of the 10 trays was separated from the other by at least $1 \mathrm{~m}$ to avoid contamination between substrates.

Table 1. Chemical characteristics of the substrates. TG: Togodo; ABD: Abdoulaye: HAM: Hahomegbe; OKM: Oti-KéranMandouri national park; FMNP: Fazao Malfakassa National Park.

\begin{tabular}{|c|c|c|c|c|c|c|}
\hline \multirow{2}{*}{ Soil parameters } & & \multicolumn{5}{|l|}{ Sites } \\
\hline & & TG & ABD & HАM & OKM & FMNP \\
\hline \multirow[t]{3}{*}{ Organic matter $(\%)$} & Carbon (C) & 3.46 & 2.420 & 2.889 & 3.035 & 2.231 \\
\hline & Total nitrogen $(\mathrm{N})$ & 2.007 & 1.403 & 1.675 & 0.123 & 0.095 \\
\hline & $\mathrm{C} / \mathrm{N}$ & 18.860 & 13.920 & 19.950 & 14.293 & 13.594 \\
\hline Phosphorus (ppm) & Assimilable Phosphorus & 3.930 & 3.210 & 3.820 & 2.810 & 2.340 \\
\hline \multirow{3}{*}{$\begin{array}{l}\text { Absorbent complex } \\
(\mathrm{meq} / 100 \mathrm{~g})\end{array}$} & Calcium $(\mathrm{Ca})$ & 4.003 & 2.508 & 1.992 & 3.754 & 1.791 \\
\hline & Sodium $(\mathrm{Na})$ & 0.017 & 0.017 & 0.015 & 0.012 & 0.017 \\
\hline & Exchange capacity (T) & 12.970 & 19.601 & 9.926 & 12.025 & 10.646 \\
\hline \multirow{3}{*}{$\begin{array}{l}\text { Salinity }(\mu \mathrm{S} / \mathrm{cm}) \\
\mathrm{pH}\end{array}$} & Electrical conductivity & 35 & 14 & 29 & 21 & 18 \\
\hline & $\mathrm{pH}\left(\mathrm{H}_{2} \mathrm{O}\right)$ & 6.990 & 6.110 & 6.140 & 6.290 & 5.730 \\
\hline & $\mathrm{pH}(\mathrm{KCl})$ & 5.930 & 5.160 & 5.300 & 5.140 & 4.580 \\
\hline
\end{tabular}

Notes: Values are the mean obtained over 4 soil samples, collected at $20 \mathrm{~cm}$ depth under 4 different fertile trees of $P$. erinaceus selected randomly in the habitat with a minimum distance of $100 \mathrm{~m}$ between trees.

\section{Seed preparation and sowing}

The seeds were collected on fertile trees at the study sites (Fig. 1). Only healthy seeds without mycelium and without deterioration were kept for the study. The obtained seeds were immersed in a beaker containing 30 $\mathrm{ml}$ of $5 \%$ calcium hypochlorite for 5 minutes. These seeds were then rinsed thoroughly with sterilized water (4 times) and immersed in 95\% ethanol for 5 minutes. The seeds were thoroughly rinsed again with sterilized water (4 times) and germinated directly in the 90 previously well-watered pots. The sowing of seeds was done in such a way as to avoid any contamination between different sets of substrates. 


\section{Experiments managing}

The experiment was carried out in the nursery of the Direction of Plant Protection (DPV) in Lomé where the temperature varies between 26 and $28{ }^{\circ} \mathrm{C}$, with a photoperiod of 12 hours of light and 12 hours of darkness. Watering of the seedlings was done regularly twice a day (morning and evening) with tap water. Two weeks after germination, growth parameters relating to length of stem, number of leaves and number of buds were regularly measured every two weeks during 20 weeks in the nursery.

\section{Data analysis}

To assess the importance of the chemical characteristics of the substrate in the growth of the seedlings, two redundancy analyses (RDA) were performed. The first analysis consisted in measuring seedlings growing on sterilized substrates and the second concerns seedlings growing on unsterilized substrates. Each of these RDAs was carried out using the 3 growth parameters namely (i) number of leaves, (ii) length of stem and (iii) number of buds, as response variables and the chemical characteristics of the substrates of the 5 sampling sites as explanatory environmental variables. The chemical components of substrates are Carbon, Total Nitrogen, Carbon / Nitrogen ratio, Assimilable Phosphorus, Calcium, Potassium, Sodium, Exchange Capacity, Electrical Conductivity, $\mathrm{pH}(\mathrm{H} 2 \mathrm{O})$ and $\mathrm{pH}(\mathrm{KCl})$. The RDAs were performed using the "vegan" library (Oksanen et al., 2019) in the R version 3.6.3 environment (R Core Team, 2020). Graphical outputs were performed using the "cleanplot.pca" function (Borcard et al., 2018).

The differences in growth observed when considering the biological characteristics of substrates were highlighted using boxplots representing the growth stage of the plants measured at the same dates throughout the experiments. In order to test the statistical significance of the observed differences in seedling growth, analyses of variances (ANOVA) at 5\% confidence level were performed on all the 3 growth parameters taken separately as response variables and considering substrates sterilization as the explanatory factor.

\section{Results}

Importance of soil-based microorganisms in the growth of $\boldsymbol{P}$. erinaceus seedlings in nursery

Normal growth of seedlings was observed on unsterilized substrates throughout the experiment (Fig. 2), unlike those growing on sterilized substrates. In fact, on unsterilized substrates, the average seedlings height increased from $5.3 \pm 1.79 \mathrm{~cm}$ after 2 weeks of growth, to $10.78 \pm 4.07 \mathrm{~cm}$ after the 4th week of growth in the nursery. Similar observations were made for seedlings growing on sterilized substrates which grew from $5.21 \pm$ $1.68 \mathrm{~cm}$ height after 2 weeks to $7.77 \pm 2.31 \mathrm{~cm}$ mean height at the 20th week. A stagnation of the height growth of young plantlets growing on sterilized substrates was observed from the 4th week until the end of the experiment $(8.75 \pm 2.32 \mathrm{~cm}$ after 20 weeks; Fig. $2 \mathrm{~A})$. On the other hand, the seedlings developing on unsterilized substrates were able to reach at the same date an average height of $19.20 \pm 5.00 \mathrm{~cm}$.

Differences in budding (Fig. 2B) and leafing (Fig. 2C) did not appear significant until the 7th week of growth. The evolution of budding and leafing of seedlings shows 3 distinct phases in sterilized substrates. After a first phase of normal growth of all seedlings, a second phase of growth stagnation was observed between the 7 th and the 14th weeks, followed by the necrosis of buds and leaf dropping after 14 weeks of growth (Fig. $2 \mathrm{~B}$ and $2 \mathrm{C}$ ), only on sterilized substrates. Indeed, the average number of buds per plantlet was almost the same for the two batches $(4.71 \pm 1.10$ buds for the plantlets growing on unsterilized substrates and $4.12 \pm$ 1.08 buds on sterilized substrates) after 6 weeks of growth. At the 14th week of growth, the average number of buds greatly increased to reach $9.16 \pm 2.16$ buds in seedlings growing on unsterilized substrates against $4.97 \pm 2.17$ buds in seedlings growing on sterilized substrates. After this date, unlike seedlings growing on unsterilized substrates, the average number of buds begins to regress in seedlings growing on sterilized substrates $(2.23 \pm 1.71$ buds at the 20th week of growth) following necrosis of existing buds. The mean number of leaves borne by both seedlings growing on unsterilized $(5.74 \pm 0.96)$ and sterilized $(5.26 \pm 0.98)$ substrates were almost similar at week 6 of growth. However, the differences started by widening between the two batches of seedlings from the 7th week to reach $9.86 \pm 2.18$ leaves for the seedlings growing on unsterilized substrates against barely $5.89 \pm 2.21$ leaves for those growing on sterilized substrates at the 14th week of growth. After this date, the seedlings growing on sterilized substrates began by gradually losing their leaves to reach an average of $3.00 \pm 1.86$ leaves per seedling while the leaves were almost stabilized in the seedlings growing on the unsterilized substrates (11.09 
\pm 2.48 leaves at the 20th week of growth; Fig. 2C).

The detrimental effect of the development of seedlings on sterilized substrates is shown by their physiological appearance. The appearance of seedlings growing on unsterilized substrates is distinguished by the greenness of their leaves and vigour of the seedlings (Fig. 3A) while the seedlings that grow on sterilized substrates show a tendency to pigmentation deficits (chlorophyll) followed by defoliation and necrosis of buds (Fig. 3B).
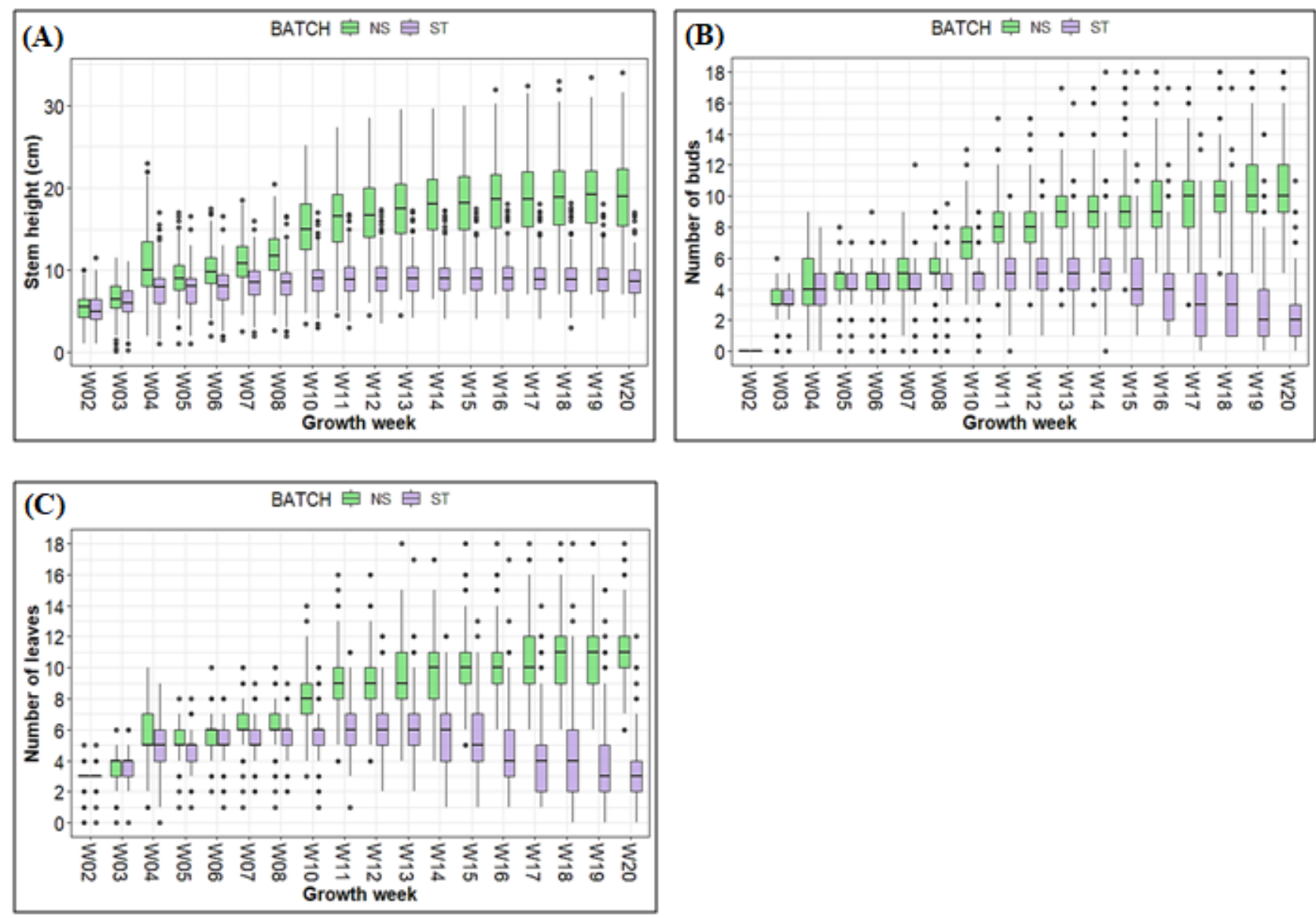

Fig. 2: Effects of sterilization of culture substrates on the growth of $P$. erinaceus seedlings in nursery. (A) Effects on height growth; (B) Effects on budding; (C) Effects on leafage; NS = Not Sterilized substrate and ST = Sterilized substrate; W = Week.
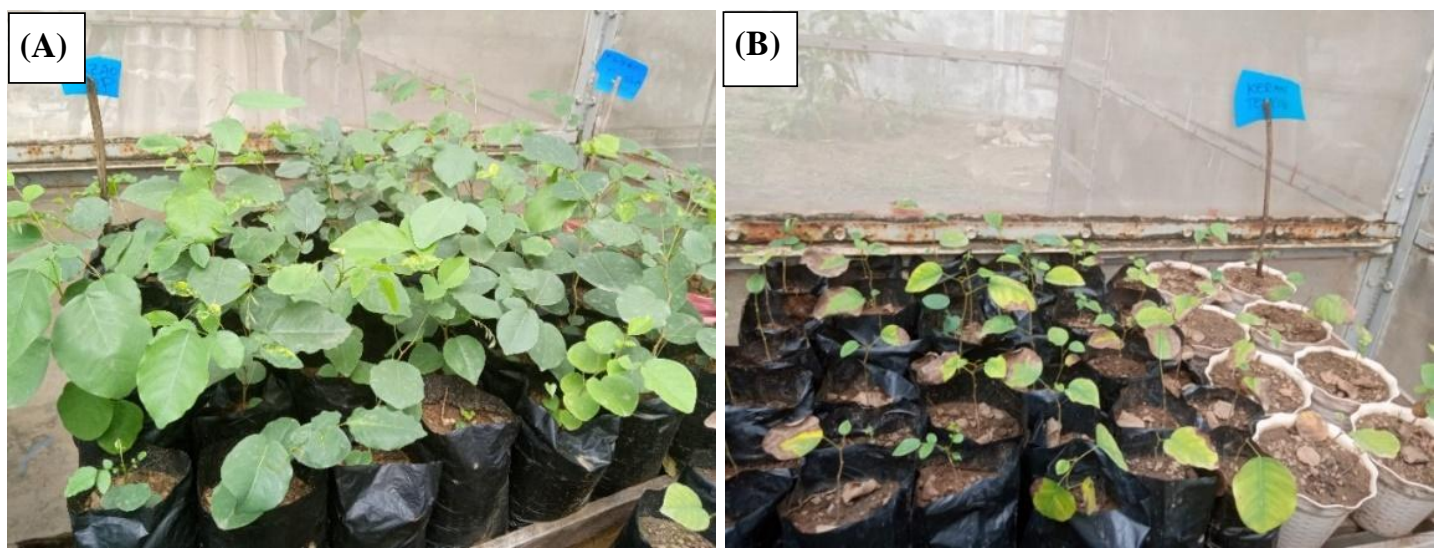

Fig. 3: Seedlings of Pterocarpus erinaceus after 20 weeks of growth on (A) Unsterilized substrates and (B) Sterilized substrates. 
Importance of the chemical characteristics of the substrate on the growth of $\boldsymbol{P}$. erinaceus seedlings in nursery

The growth (leafing, budding and height growth) of $P$. erinaceus seedlings depends on the chemical characteristics of the substrate on which they grow (Fig. 4). Their growth is significantly correlated with carbon levels of $(p$-value $=0.008)$, calcium $(p$-value $=0.005)$ and $\mathrm{pH}(\mathrm{H} 2 \mathrm{O})(\mathrm{p}$-value $=0.028)$ of the substrates in an unsterilized conditions. However, these chemical constituents of the substrates do not alone explain the observed differences in growth between seedlings. According to the RDA of seedlings grown on unsterilized substrates (Fig. 4A), the first two axes together explained about $99.75 \%$ of the overall variation in the seedlings' growth. The first two axes of the RDA of sterilized substrates' seedlings (Fig. 4B) explained about $98.39 \%$ of the overall variation in seedlings' growth. For both RDAs, axis 1 represents the growth in height, while axis 2 is correlated to budding and leafing. The more seedlings bear buds, the less they bear leaves. On unsterilized substrates, seedlings bear few leaves and more buds when the substrate contains more Calcium, Carbon and is less acid (high $\mathrm{pH}\left(\mathrm{H}_{2} \mathrm{O}\right)$ ). Analysis of growth parameters for sterilized substrates (Fig. 4B) shows that almost all the chemical constituents of the substrate with the exception of Calcium ( $\mathrm{p}$-value $=0.156$ ) are determining in the growth in height, leafing and budding of seedlings. Among these parameters, Phosphorus ( $\mathrm{p}$-value $=0.001$ ), Nitrogen $(\mathrm{p}$-value $=0.001)$, Potassium $(\mathrm{p}$-value $=$ $0.001)$, Carbon / Nitrogen ratio $(\mathrm{p}$-value $=0.001)$ and $\mathrm{pH}(\mathrm{KCl})(\mathrm{p}$-value $=0.001)$ explain the differences in budding and leafing of seedlings in nursery. Seedlings bear more leaves with the increase in Nitrogen and Potassium in the substrate. A better height growth is obtained with lower Phosphorus, $\mathrm{pH}$ and $\mathrm{C} / \mathrm{N}$ ratio.
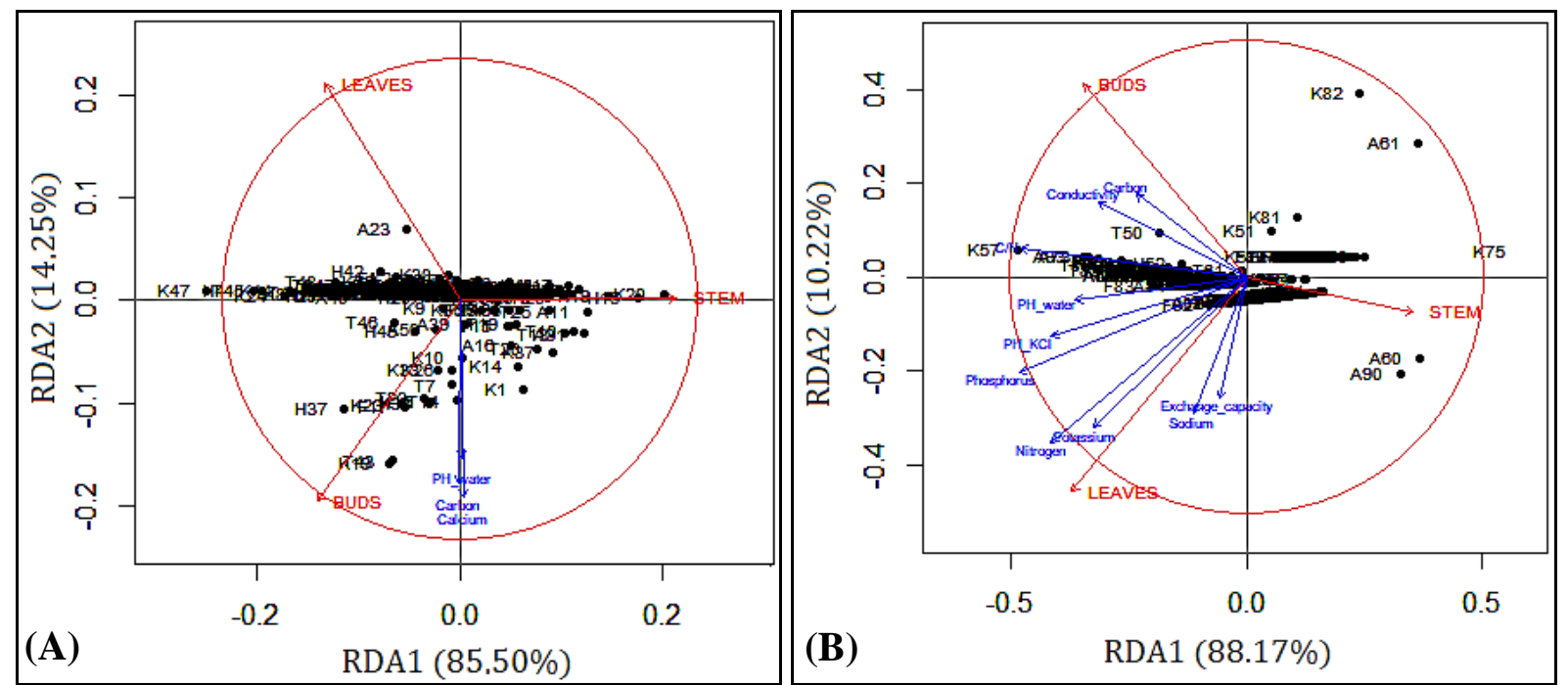

Fig. 4: RDA plots of the importance of chemical characteristics of the substrate on the growth of seedlings of Pterocarpus erinaceus growing (A) on unsterilized substrates; (B) on sterilized substrate.

\section{Discussion}

This study shows that telluric microorganisms play a determining role in the growth of Pterocarpus erinaceus seedlings in nursery. Indeed, seedling growth parameters on sterilized and unsterilized substrates from 5 sites are significantly different. The beneficial actions of the infectious potential of the microorganisms of the substrates taken from the natural habitat of the species could explain the differences in growth observed between the seedlings of sterilized substrates and those of unsterilized substrates, starting from the 4th week for height growth and from the 7th week for budding and leafing. Several authors have highlighted the importance of nitrogen-fixing rhizobia and mycorrhizal fungi as essential elements involved in improving the bioavailability of soil nutrients and plant productivity (Mohammadi and Sohrabi, 2012). It was demonstrated that in forest ecosystems, trees cannot survive without mycorrhizae (Le Tacon et al., 1997). Other similar works show that some plant species cannot grow normally without associating with a fungal partner 
(Gobat et al., 2010; Janos, 1980). These fungal partners are involved in all stages of the development of tree species (Smith and Smith, 1997; Smith and Read, 2010). Nitrogen-fixing rhizobia especially found in the Leguminosae have been widely touted as equally beneficial microorganisms as mycorrhizal fungi.

A wide range of Plants Beneficial Rhizospheric Microorganisms (PBRMs) like rhizobacteria, fungi and actinomycetes are beneficial to plants. While associated with plant roots, they promote the growth of the host plant under natural agro-ecosystem through various mechanisms, namely biological nitrogen fixation (Meena et al., 2017; Recous et al., 2017), the solubilization of phosphorus (Gupta et al., 2020; Rawat et al., 2021), potassium (Bahadur et al., 2016; Nath et al., 2017), production of plant growth regulators (Beauchamp, 2005; Ma et al., 2011; Shi et al., 2017). The inoculation of Mucuna pruriens in a controlled conditions (Haro et al., 2020) with a mixed inoculum of Scutellospora sp., Gigaspora sp. and Glomus sp (Haro, 2016) of on the one hand and Glomus aggregatum on the other hand, revealed an improvement in height growth of $225.76 \%$, aboveground biomass of $56.79 \%$, root biomass of $70 \%$ and total biomass of $61.16 \%$ relative to uninoculated controls. Furthermore, the results of agronomic trials after co-inoculation of Rhizobium leguminosarum and Azotobacter chrococcum showed an increased aerial biomass by $14 \%$ in comparison with inoculation of the Rhizobium leguminosarum strain alone.

The results of the present study support the conclusions that soil microorganisms in general, are essential for tree species' proper growth, without however making a distinction between the actions of the different types of microorganisms present in the growing substrate. It is possible that these different types of microorganism play complementary roles, some in the fixation of nitrogen (especially rhizobia), others in the mobilization of other soil nutrients such as Phosphorus and Potassium. In addition, it is also possible that the microorganisms are different from one site to another, with potentially different nutrients mobilization potentials. The withering tendency observed on all batches of plants grown on sterilized substrates from the 7 th week of growing, unlike those grown on unsterilized substrates, could therefore be explained by the lack of microorganisms following sterilization of substrates.

The current study also sheds light on the influence of soil nutrients on growth height, leafing and budding of plants. Seedling budding and leafing are linked to concentrations of Phosphorus, Nitrogen, Potassium, Carbon / Nitrogen ratio and $\mathrm{pH}(\mathrm{KCl})$ in sterilized substrates. These growth differences, which do not depend on microorganisms' potentials, demonstrate the role of soil nutrients in the growing of $P$. erinaceus seedlings at their first stage of growth. These results show that in the nursery, plants need these chemical elements in the soil to grow properly (Leroy et al., 1973; Lévy, 1975; Meena et al., 2017). However, it is important to note that the influence of the chemical constituents on the growth of seedlings seems negligible compared to the presence of microorganisms. Seedlings have enormous difficulty in passing a certain level of development in the absence of microorganisms, regardless of the chemical composition of the substrate. These results show unequivocally that the normal and sustained development of the plantlets of $P$. erinaceus necessarily involves the presence of microorganisms and some chemical constituents in the substrate. These results show that for the production of $P$. erinaceus seedlings, microorganisms should constitute a determining biological factor in the success of the nursery. It would then be interesting to determine the role of each type or species of microorganism in the proper development of seedlings.

\section{Conclusions}

This study has revealed the importance of microorganisms for the growth of $P$. erinaceus seedlings in the nursery. These microorganisms are essential for the proper development of seedlings and are decisive for their survival both in nursery and in the plantation. Microorganisms play a key role in mobilizing soil nutrients such as Phosphorus, Potassium and Nitrogen for the benefit of young seedlings. The study makes it possible to overcome the difficulties relating to the survival of young seedlings during their growth in the nursery. It is now advisable in the technical itineraries of the production of $P$. erinaceus seedlings to use natural substrates, especially those taken from the natural stands of the species in order to increase the chances of obtaining the beneficial effect of microorganisms naturally growing in association with it.

\section{Conflict of interest statement}

Authors declare that they have no conflict of interest. 


\section{Acknowledgement}

The authors are grateful to all the following partners for their financial and technical support which made this study possible:

- the "Sud Expert Plantes et Développement Durable" (SEP2D) program,

- the Economic Community of West African States (ECOWAS), through the ECOWAS Research and Innovation Support Program (PARI program),

- the "Agence Universitaire de la Francophonie" (AUF),

- the "Service de Coopération et d'Action Culture" (SCAC) of France embassy in Togo,

- the "Deutsche Gesellschaft für Internationale Zusammenarbeit" (GIZ)-Togo,

- the European Union through the Global Alliance for Climate Change (GCCA),

- the Togolese government through the "Institut Togolais de Recherche Agronomique", (ITRA) and the "Direction de la Protection des Végétaux" (DPV).

\section{References}

Abbas, Y., Bakkali-Yakhlef, S., Prin, Y., Arahou, M., Abourouh, M., Duponnois, R., 2013. Growth and nutrition of Tetraclinis articulata (Vahl) Mast. cultivated in different rhizosphere soils collected from Tetraclinis stand. Biotechnol. Agron. Soc. Environ., 17: 3-11.

Adjonou, K., Abotsi, K.E., Segla, K.N., Rabiou, H., Houetchegnon, T., Sourou, K.N.B., Johnson, B.N., Ouinsavi, C.A.I.N., Kokutse, A.D., Mahamane, A., Kokou, K., 2020. Vulnerability of African Rosewood (Pterocarpus erinaceus, Fabaceae) natural stands to climate change and implications for silviculture in West Africa. Heliyon, 6: e04031.

Adjonou, K., Ali, N., Kokutse, A.D., Segla, K.N., 2010. Etude de la dynamique des peuplements naturels de Pterocarpus erinaceus Poir. (Fabaceae) surexploités au Togo. Bois For. Trop., 306: 45-55.

Alaba, P., Abotsi, K.E., Adjonou, K., Segla, K.N., Kokutse, A.D., Kokou, K., 2020. Analyse des connaissances sur Pterocarpus erinaceus Poir. en Afrique Occidentale et Centrale. Eur. Scient. J., 16: 157-172.

Alkemade, R., Oorschot, M. van, Miles, L., Nellemann, C., Bakkenes, M., Brink, B. ten, 2009. GLOBIO3: A framework to investigate options for reducing global terrestrial biodiversity loss. Ecosystems, 12:
374-390.

Bahadur, I., Maurya, B.R., Kumar, A., Meena, V.S., Raghuwanshi, R., 2016. Towards the soil sustainability and potassium-solubilizing microorganisms. In: Meena, V.S., Maurya, B.R., Verma, J.P., Meena, R.S. (Eds.), Potassium Solubilizing Microorganisms for Sustainable Agriculture. Springer India, New Delhi, pp. 255266.

Bamba, N., Ouattara, N.D., Konan, D., Bakayoko, A., Tra Bi, F.H., 2018. Effets de cinq prétraitements sur la germination du vène (Pterocarpus erinaceus Poir., Fabaceae) dans la Réserve du Haut Bandama (Côte d'Ivoire). Eur. Scient. J., 14: 438-453.

Beauchamp, C.J., 2005. Mode d'action des rhizobactéries favorisant la croissance des plantes et potentiel de leur utilisation comme agent de lutte biologique. Phytoprotection, 74: 19-27.

Borcard, D., Gillet, F., Legendre, P., 2018. Numerical Ecology with R, 2nd Edn., Springer, New York.

Dumenu, W.K., 2019. Assessing the impact of felling/export ban and CITES designation on exploitation of African rosewood (Pterocarpus erinaceus). Biol. Conserv., 236: 124-133.

Duvall, C., 2008. Pterocarpus erinaceus Poir. Prota 7.

El-Siddig, K., 2006. Tamarind: Tamarindus indica L. International Centre for Underutilised Crops, Univ. of Southampton, Southampton.

Ern, H., 1979. Die Vegetation Togos. Gliederung, Gefährdung, Erhaltung. Willdenowia 9, 295-312.

Giddings, B., Hopwood, B., O’Brien, G., 2002. Environment, economy and society: fitting them together into sustainable development. Sustain. Develop., 10: 187-196.

Gobat, J.-M., Aragno, M., Matthey, W., 2010. Le sol vivant: bases de pédologie, biologie des sols. PPUR Presses polytechniques.

Gupta, V., Kumar, G.N., Buch, A., 2020. Colonization by multi-potential Pseudomonas aeruginosa $\mathrm{P} 4$ stimulates peanut (Arachis hypogaea L.) growth, defence physiology and root system functioning to benefit the root-rhizobacterial interface. Journal of Plant Physiol., 248: 153144.

Haro, H., 2016. Optimisation des symbioses rhizobienne et mycorhizienne pour améliorer la productivité du niébé [Vigna unguiculata (L.) Walp.] au Burkina Faso (PhD Thesis). Université Ouaga 1, Ouagadougou, Burkina Faso.

Haro, H., Semde, K., Bahadio, K., Sanon, K.B., 2020. Effet de l'inoculation mycorhizienne avec des souches des champignons mycorhiziens 
arbusculaires sur la croissance de Mucuna pruriens (L.) DC en condition contrôlée. Int. J. Bio. Chem. Sci., 14: 1065-1073.

Imane, O., Atmane, R., El Yacoubi, H., Sara, E.-C., Younes, A., 2019. Potentiality exploration of native arbuscular mycorrhizal fungi in Argania spinosa (L.) Skeels growth under nursery conditions. Plant Cell Biotechnol. Mol. Biol., 20: 1320-1330.

IUCN, 2020. The IUCN Red List of Threatened Species. Version 2020-2 [WWW Document]. URL https://www.iucnredlist.org (accessed 7.9.20).

Janos, D.P., 1980. Vesicular-arbuscular mycorrhizae affect lowland tropical rain forest plant growth. Ecology, 61: 151-162.

Le Tacon, F., Mousain, D., Garbaye, J., Bouchard, D., Churin, J.-L., Argillier, C., Amirault, J.-M., Genere, B., 1997. Mycorhizes, pépinières et plantations forestières en France. Rev. For. Franç., 49: 131154.

Leroy, Ph., Lévy, G., Strullu, D.G., 1973. Action de la matière organique et des engrais minéraux en pépinière sur la croissance et les caractères foliaires du Douglas. Ann. Sci. Forest., 30: 393-412.

Lévy, G., 1975. Recherche de la fertilisation optimale d'un sol de pépinière. Ann. Sci. Forest., 32: 135-141.

Ma, Y., Rajkumar, M., Luo, Y., Freitas, H., 2011. Inoculation of endophytic bacteria on host and nonhost plants-Effects on plant growth and Ni uptake. J. Hazard. Mat., 195: 230-237.

Meena, V.S., Meena, S.K., Verma, J.P., Kumar, A., Aeron, A., Mishra, P.K., Bisht, J.K., Pattanayak, A., Naveed, M., Dotaniya, M.L., 2017. Plant beneficial rhizospheric microorganism (PBRM) strategies to improve nutrients use efficiency: a review. Ecol. Eng., 107: 8-32.

Mohammadi, K., Sohrabi, Y., 2012. Bacterial biofertilizers for sustainable crop production: a review. ARPN J. Agric. Biol. Sci., 7: 307-316.

Nacoulma, B.M.I., Traoré, S., Hahn, K., Thiombiano, A., 2011. Impact of land use types on population structure and extent of bark and foliage harvest of Afzelia africana and Pterocarpus erinaceus in Eastern Burkina Faso. Int. J. Biodivers. Conserv., 3: 62-72.

Nath, D., Maurya, B.R., Meena, V.S., 2017. Documentation of five potassium- and phosphorussolubilizing bacteria for their $\mathrm{K}$ and $\mathrm{P}$-solubilization ability from various minerals. Biocatal. Agric. Biotechnol., 10: 174-181.

Neyra, M., Sow, H.A., Dia, M., Ndoye, I., Kane, A., Diouf, D., Yattara, I., Jankowski, F., Le Marec, J.,
Le Quéré, A., Wade, T., 2012. Inoculation des plantes cultivées avec des micro-organismes symbiotiques: du transfert de technologie à la construction d'un partenariat multi-acteurs. In: Dia, A., Duponnois, R. (Eds.), La Grande Muraille Verte: capitalisation des recherches et valorisation des savoirs locaux, Synthèses. IRD, Marseille, pp. 379392.

Oksanen, J., Blanchet, F.G., Friendly, M., Kindt, R., Legendre, P., McGlinn, D., Minchin, P.R., O'Hara, R.B., Simpson, G.L., Solymos, P., Stevens, M.H.H., Szoecs, E., Wagner, H., 2019. vegan: Community Ecology Package.

Ouinsavi, C., Sourou, B., Houètchégnon, T., Wédjangnon, A., Dossa, B., Akin, Y., Dossou, J., Houndjo, M.R., 2019. Effect of cuttings diameter and indol acetic acid on rooting of Pterocarpus erinaceus Poir. stem cuttings. Int. J. Agrofor. Silvicult., 7: 1-10.

R-Core Team, 2020. R: A Language and Environment for Statistical Computing. $\mathrm{R}$ Foundation for Statistical Computing, Vienna, Austria.

Rabiou, H., Bationo, A.B., Abdou, L., Segla, K.N., Adjonou, K., Kokutse, A.D., 2017a. Vegetative propagation by aerial layering of Pterocarpus erinaceus: In the Sudanian zone. Int. J. Recent Adv. Multidiscipl. Res., 4: 2902-2908.

Rabiou, H., Bationo, B.A., Adjonou, K., Kokutse, A.D., Mahamane, A., Kokou, K., 2017b. Perception paysanne et importance socioculturelle et ethnobotanique de Pterocarpus erinaceus au Burkina Faso et au Niger. Afr. Sci., 13: 43-60.

Rawat, P., Das, S., Shankhdhar, D., Shankhdhar, S.C., 2021. Phosphate-solubilizing microorganisms: Mechanism and their role in phosphate solubilization and uptake. J. Soil Sci. Plant Nutr., 21: 49-68.

Recous, S., Lashermes, G., Bertrand, I., 2017. Couplages et contrôles des cycles du carbone et de l'azote par les communautés microbiennes dans les sols cultivés, in: Les sols et la vie souterraine: des enjeux majeurs en agroécologie, Synthèses (Quae). Editions Quae, pp. 43-62.

Riedacker, A., 1993. Physiologie des arbres et arbustes en zones arides et semi-arides: séminaire, ParisNancy, 20 mars-6 avril 1990. John Libbey Eurotext, Montrouge, France.

Rincón, A., Valladares, F., Gimeno, T.E., Pueyo, J.J., 2008. Water stress responses of two Mediterranean tree species influenced by native soil microorganisms and inoculation with a plant growth 
promoting rhizobacterium. Tree physiology 28, 1693-1701.

Sali, B., Fatimata, N., Macoumba, D., Patrick45, V.D., 2011. Effets de l'inoculation mycorhizienne sur le comportement agro-physiologique des écotypes du tamarinier (Tamarindus indica L.) au Sénégal. J. Appl. Biosci., 46: 3093-3102.

Segla, K.N., Adjonou, K., Radji, A.R., Kokutse, A.D., Kokou, K., Habou, R., Kamana, P., Bationo, B.A., Mahamane, A., 2015a. Importance socioéconomique de Pterocarpus erinaceus Poir. au Togo. Eur. Scient. J., 11 : 199-217.

Segla, K.N., Kokutse, A.D., Adjonou, K., Langbour, P., Chaix, G., Guibal, D., Kokou, K., 2015b. Caractéristiques biophysiques $\mathrm{du}$ bois de Pterocarpus erinaceus (Poir.) en zones guinéenne et soudanienne au Togo. Bois For Trop., 324: 51-64.

Segla, N.K., Rabiou, H., Adjonou, K., Moussa, B.M., Saley, K., Radji, R.A., Kokutse, A.D., Bationo, A.B., Mahamane, A., Kokou, K., 2016. Population structure and minimum felling diameter of
Pterocarpus erinaceus Poir in arid and semi-arid climate zones of West Africa. South Afr. J. Bot., 103: 17-24.

Shi, T.-Q., Peng, H., Zeng, S.-Y., Ji, R.-Y., Shi, K., Huang, H., Ji, X.-J., 2017. Microbial production of plant hormones: Opportunities and challenges. Bioengineered, 8: 124-128.

Smith, F.A., Smith, S.E., 1997. Structural diversity in (vesicular)-arbuscular mycorrhizal symbioses. New Phytologist, 137: 373-388.

Smith, S.E., Read, D.J., 2010. Mycorrhizal Symbiosis. Academic Press.

Solly, B., Charahabil, M., Dieye, E.B., Sy, O., Barry, B., Sagna, B., Faye, C., 2020. Impacts of natural and anthropogenic factors on the woody flora of HauteCasamance (south Senegal): from perception to reality. J. Appl. Sci. Environ. Stud., 3: 117-131.

Zida, D., Tigabu, M., Sawadogo, L., Oden, P.C., 2005. Germination requirements of seeds of four woody species from the Sudanian savanna in Burkina Faso, West Africa. Seed Sci. Technol., 33: 581-593.

\section{How to cite this article:}

Alaba, P., Tchabi, A., Abotsi, K. E., Adjonou, K., Segla, K. N., Kokutse, A. D., Kokou, K., 2021. Effect of nursery substrate on the growth of Pterocarpus erinaceus Poir. seedlings. Int. J. Curr. Res. Biosci. Plant Biol., 8(9): 17-27.

doi: https://doi.org/10.20546/ijcrbp.2021.809.003 